\title{
"Mohsite" of Colomba: Identification as Dessauite-(Y)
}

\author{
Erica Bittarello, ${ }^{1}$ Marco E. Ciriotti, ${ }^{2}$ Emanuele Costa, ${ }^{1}$ and Lorenzo Mariano Gallo ${ }^{3}$ \\ ${ }^{1}$ Dipartimento di Scienze della Terra, Via Tommaso Valperga Caluso 35, 10125 Torino, Italy \\ ${ }^{2}$ Associazione Micromineralogica Italiana, Via San Pietro 55, 10073 Devesi-Ciriè, Torino, Italy \\ ${ }^{3}$ Museo Regionale di Scienze Naturali, Via Giovanni Giolitti 36, 10123 Torino, Italy
}

Correspondence should be addressed to Emanuele Costa; emanuele.costa@unito.it

Received 11 November 2013; Revised 6 March 2014; Accepted 20 March 2014; Published 8 April 2014

Academic Editor: Elena Belluso

Copyright (C) 2014 Erica Bittarello et al. This is an open access article distributed under the Creative Commons Attribution License, which permits unrestricted use, distribution, and reproduction in any medium, provided the original work is properly cited.

During a reorganization of the mineralogical collection of Turin University, old samples of the so-called mohsite of Colomba were found. "Mohsite" was discredited in 1979 by Kelly et al., as a result of some analyses performed on the equivalent material coming from the French region of Hautes-Alpes, but the original samples found in similar geological setting in Italy were lost and never analysed with modern equipment. After more than a century, the rediscovered samples of Professor Colomba were analysed by means of SEM-EDS analysis, microRaman spectroscopy, and X-ray diffraction. The results have demonstrated that the historical samples studied by Colomba are $\mathrm{Pb}$-free dessauite-(Y), and pointed to an idealized crystal chemical formula $\left(\mathrm{Sr}_{0.70} \mathrm{Na}_{0.25} \mathrm{Ca}_{0.09}\right)_{\Sigma=1.04}\left(\mathrm{Y}_{0.62} \mathrm{U}_{0.18} \mathrm{Yb}_{0.09} \mathrm{Sc}_{0.08}\right)_{\Sigma=0.97} \mathrm{Fe}_{2}^{2+}\left(\mathrm{Ti}_{12.66} \mathrm{Fe}_{4.78}^{3+} \mathrm{V}_{0.26}^{3+}\right)_{\Sigma=17.70} \mathrm{O}_{38}$ and unit-cell parameters $a=10.376(3) \AA, c=$ 20.903(6) $\AA$, and $V=1949(1) \AA^{3}$.

\section{Introduction}

"Mohsite" was first cited in 1827 by Lévy [1] in rock samples from the Dauphiné region (France). The identification was obtained mainly on morphological evidence, but the original samples studied by Lévy were lost, and no other analysis could be made for a better identification.

In 1901, Lacroix [2] acquired some samples coming from Le Plate Muratouse, La Grave area, at the Department of Hautes-Alpes (Provence-Alpes-Côte d'Azur, France). Based only on the morphological features, very similar to those described by Lévy, and considering the close topographical occurrence, Lacroix identified these samples as "mohsite" and, since the old types were missing, the new samples became neotypes.

One year later, Colomba [3], at that time, Professor of Mineralogy at the Royal University and Director of the Mineralogical Museum of Turin (Piedmont, Italy), described morphologically similar small crystals coming from La Beaume, Oulx (Susa Valley, Piedmont, Italy) not so far from the French occurrence and in a comparable geological and mineralogical context (Colomba, [3]). Chemical qualitative analysis carried out by Colomba showed only the presence of $\mathrm{TiO}, \mathrm{CaO}, \mathrm{FeO}$, and minor $\mathrm{MgO}$. The data of Colomba were later summarized by Zambonini [4].

These samples (few millimetric size crystals) were lost in some drawer of the University Museum Warehouse and forgotten for about a century (Costa and Gallo, [5]). Kelly et al. [6] reported that they had obtained some of the samples of the Lacroix collection and gave additional data on them.

The analysis performed by Kelly showed the presence of $\mathrm{Sr}$ and minor $\mathrm{Pb}$, but not calcium, so the mineral of Lacroix and Colomba was not the new Ca-rich member of the crichtonite supergroup, which was named loveringite by Gatehouse et al. [7]. These authors consequently stated that the name "mohsite" was incorrectly used for a member of the crichtonite-senaite series, they proposed to discredit the name "mohsite," and IMA accepted the proposal.

In 2008, during the reorganization of the historical mineralogical collection of the University of Turin, Italy (now hosted in the Regional Museum of Natural History of the same town, MRSN hereinafter), some old wooden boxes were opened, and the original samples, together with the handwritten label of Colomba, at that time, Director of 
TABLE 1: Crichtonite supergroup minerals (after Mills et al., 2012 [16]), revised and updated.

\begin{tabular}{|c|c|c|c|c|c|}
\hline Species & ${ }^{\mathrm{XII}} \mathrm{A}$ & ${ }^{\mathrm{VI}} \mathrm{B}$ & ${ }^{\mathrm{IV}} \mathrm{T}_{2}$ & ${ }^{\mathrm{VI}} \mathrm{C}_{18}(\Phi)_{38}$ & Reference \\
\hline Almeidaite & $\mathrm{Pb}$ & $\mathrm{Mn}, \mathrm{Y}$ & $\mathrm{Zn}_{2}$ & $\mathrm{Ti}, \mathrm{Fe}$ & {$[17]$} \\
\hline Cleusonite & $\mathrm{Pb}, \mathrm{Sr}$ & $\mathrm{U}$ & $(\mathrm{Fe}, \mathrm{Zn})_{2}$ & $\mathrm{Ti}, \mathrm{Fe}$ & {$[18]$} \\
\hline Crichtonite & $\mathrm{Sr}, \mathrm{Pb}, \mathrm{Ba}$ & $\mathrm{Mn}$ & $(\mathrm{Fe}, \mathrm{Zn})_{2}$ & $\mathrm{Ti}, \mathrm{Fe}$ & {$[19]$} \\
\hline Davidite-(La) & $\mathrm{La}, \mathrm{Ce}, \mathrm{Ca}$ & Y, HREE, U & $(\mathrm{Fe}, \mathrm{Mg})_{2}$ & Ti, Fe, Cr, V & {$[20]$} \\
\hline Davidite-(Ce) & $\mathrm{Ce}, \mathrm{La}$ & Y, HREE, U & $(\mathrm{Fe}, \mathrm{Mg})_{2}$ & Ti, Fe, Cr, V & {$[20]$} \\
\hline Dessauite-(Y) & $\mathrm{Sr}, \mathrm{Pb}$ & $\mathrm{Y}, \mathrm{U}$ & $(\mathrm{Fe}, \mathrm{Zn})_{2}$ & $\mathrm{Ti}, \mathrm{Fe}$ & {$[8]$} \\
\hline Gramaccioliite-(Y) & $\mathrm{Pb}, \mathrm{Sr}$ & $\mathrm{Y}, \mathrm{Mn}$ & $(\mathrm{Fe}, \mathrm{Zn})_{2}$ & $\mathrm{Ti}, \mathrm{Fe}$ & [9] \\
\hline Landauite & $\mathrm{Na}, \mathrm{Pb}$ & Mn, Y & $\mathrm{Zn}_{2}$ & $\mathrm{Ti}, \mathrm{Fe}, \mathrm{Nb}$ & {$[21]$} \\
\hline Lindsleyite & $\mathrm{Ba}, \mathrm{K}$ & $\mathrm{Zr}, \mathrm{Fe}$ & $(\mathrm{Mg}, \mathrm{Fe})_{2}$ & $\mathrm{Ti}, \mathrm{Cr}, \mathrm{Fe}$ & {$[22]$} \\
\hline Loveringite & $\mathrm{Ca}, \mathrm{LREE}$ & $\mathrm{Zr}, \mathrm{Fe}$ & $(\mathrm{Mg}, \mathrm{Fe})_{2}$ & $\mathrm{Ti}, \mathrm{Fe}, \mathrm{Cr}, \mathrm{Al}$ & {$[7]$} \\
\hline Mapiquiroite & $\mathrm{Sr}, \mathrm{Pb}$ & $\mathrm{U}, \mathrm{Y}$ & $\mathrm{Fe}_{2}$ & $\mathrm{Ti}, \mathrm{Fe}, \mathrm{Cr}$ & {$[23]$} \\
\hline Mathiasite & $\mathrm{K}, \mathrm{Ba}, \mathrm{Sr}$ & $\mathrm{Zr}, \mathrm{Fe}$ & $(\mathrm{Mg}, \mathrm{Fe})_{2}$ & $\mathrm{Ti}, \mathrm{Cr}, \mathrm{Fe}$ & {$[22,24]$} \\
\hline Paseroite & $\mathrm{Pb}, \mathrm{Sr}$ & $\mathrm{Mn}$ & $(\mathrm{Mn}, \mathrm{Fe})_{2}$ & $\mathrm{~V}, \mathrm{Ti}, \mathrm{Fe}$ & {$[16]$} \\
\hline Senaite & $\mathrm{Pb}, \mathrm{Sr}$ & $\mathrm{Mn}$ & $(\mathrm{Fe}, \mathrm{Zn})_{2}$ & $\mathrm{Ti}, \mathrm{Fe}$ & [19] \\
\hline
\end{tabular}

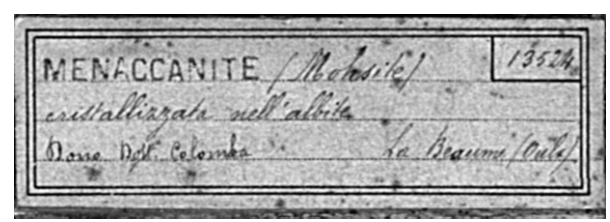

FIgURE 1: Original label manuscript by Colomba. The translation from Italian says: "MENACCANITE [sic] (mohsite) crystallized in albite-Gift of Dr. Colomba-La Beaume (Oulx)" with catalogue number (13524).

the Museum (who stored them with a label "manaccanite," a Mg-rich variety of ilmenite), and the original catalogue number, M/U 13524, were newly found (Figure 1).

Two small crystals were analysed in the laboratory of the Department of Earth Science of the University of Turin and of the CrisDi (Interdepartmental Centre for the Research and Development of Crystallography, Turin, Italy) for the identification.

The analyses demonstrate that the old specimens are dessauite-(Y) (Orlandi et al. [8]).

Dessauite-(Y) is a rare member of the crichtonite supergroup and occurs as few millimetres flattened rhombohedral crystals, tabular $\{001\}$ with hexagonal outline, black or blackish brown in colour, and metallic up to subadamantine lustre.

This paper deals with clarifying the identification of historical samples, rediscovered after many years, using modern analytical techniques, and it gives additional information on known mineral species, such as the Raman spectrum of dessauite-(Y) and gramaccioliite-(Y) (Orlandi et al. [9]), until now never published. In addition, it is interesting to outline that the occurrence of dessauite-(Y) in La Beaume (Oulx, Susa Valley, Piedmont, Italy) represents the first probed finding for the Piedmont region and the fourth finding for Italy.

\section{The Crichtonite Supergroup}

The minerals of the crichtonite supergroup belong to the oxide class containing medium to high size cations (Table 1). The structural formula of the group is ${ }^{\mathrm{XII}} \mathrm{A}{ }^{\mathrm{VI}} \mathrm{B}$ ${ }^{\mathrm{IV}} \mathrm{T}_{2}{ }^{\mathrm{VI}} \mathrm{C}_{18}(\Phi)_{38}$, where ${ }^{\mathrm{XII}} \mathrm{A}=\mathrm{Ba}, \mathrm{K}, \mathrm{Pb}, \mathrm{Sr}$, La, Ce, $\mathrm{Na}$, $\mathrm{Ca} ;{ }^{\mathrm{VI}} \mathrm{B}=\mathrm{Mn}, \mathrm{Y}, \mathrm{U}, \mathrm{Fe}, \mathrm{Zr}, \mathrm{Sc} ;{ }^{\mathrm{IV}} \mathrm{T}_{2}=\mathrm{Fe}, \mathrm{Mg}, \mathrm{Zn} ;{ }^{\mathrm{VI}} \mathrm{C}_{18}=\mathrm{Ti}$, $\mathrm{Fe}, \mathrm{Cr}, \mathrm{Nb}, \mathrm{V}, \mathrm{Mn}$; and $(\Phi)_{38}=\mathrm{O},(\mathrm{OH}), \mathrm{F}$ (Wülser et al. [10]). These minerals are isostructural, crystallizing in the trigonal system, space group $R-3$, with lattices $a=10.28-10.576 \AA$ and $c=20.52-21.325 \AA$, and they present a great variability of composition (only $\mathrm{Ti}$ and $\mathrm{Fe}$ are systematically present).

\section{Material and Methods}

The choice of analytical methods was oriented on nondestructive analyses, due to the scarcity, the small dimensions, and the historical relevance of the samples.

The chemical composition was obtained with semiquantitative, nondestructive EDS microanalysis, for determination of major and minor elements; microRaman spectroscopy was used for identification purposes and spectrum collection. Crystallographic data were achieved by X-ray diffraction.

EDS data were acquired by SEM-EDS analysis using a Cambridge Stereoscan 360 Scanning Electron Microscope, equipped with an Oxford Inca Energy 200 EDS Microanalysis, Pentafet detector, and ultrathin window for the determination of elements with $Z$ number down to boron. All the spectra were obtained at $15 \mathrm{kV}$ accelerating voltage, $25 \mathrm{~mm}$ working distance, and $1 \mu \mathrm{A}$ probe current, for time comprising between 60 and 300 seconds. Primary standardization was performed on SPI Supplies and Polaron 
Equipment analytical standards and daily standardization performed on high purity metallic cobalt standard. A good quantitative analysis usually requires a very flat and polished surface, but this could have been obtained only by causing the destruction of the sample. So a small crystal was instead glued on carbon conductive tape and graphitized for analysis.

X-ray powder and single-crystal diffraction studies were carried out using an Oxford Gemini R Ultra diffractometer equipped with a CCD area detector at CrisDi (Interdepartmental Centre for the Research and Development of Crystallography, Torino, Italy). Graphite-monochromatized MoK $\alpha$ radiation $(\lambda=0.71073 \AA)$ was used.

Unpolarized microRaman spectra were obtained on an unpolished crystal with a Jobin-Yvon Horiba model LabRam HRVIS, using a motorized $\mathrm{x}-\mathrm{y}$ stage and an Olympus microscope with a 50x objective.

The backscattered Raman signal was collected with 50x objective and the Raman spectrum was obtained for a nonoriented crystal. The $632.8 \mathrm{~nm}$ line of a He-Ne laser was used as excitation; laser power was controlled by means of a series of density filters. The minimum lateral and depth resolution was set to few $\mu \mathrm{m}$. The system was calibrated using the $520.6 \mathrm{~cm}^{-1}$ Raman band of silicon before each experimental session. The spectra were collected with multiple acquisitions (2 to 6) with single counting times ranging between 20 and 120 seconds. Spectral manipulation such as baseline adjustment, smoothing, and normalization were performed using the Labspec 5 software package. Band component analysis was undertaken using the Fityk software package (Wojdyr [11]), which enabled the type of fitting function to be selected and allows specific parameters to be fixed or varied accordingly.

\section{Results and Discussion}

\subsection{Chemical and Spectroscopic Data}

4.1.1. EDS Analyses. One of the two well-formed crystals, millimetres in size, found in the old material of the MRSN (Turin, Italy), was analysed (Figure 2). A total of 10 point analyses were collected with homogeneous results for major and minor elements, and the analytical data are reported in Table 2. In Figure 3, the position of some analyses points obtained on different clean and almost flat faces of the crystal is visible.

Main elements correspond to titanium, iron, yttrium, strontium, uranium, ytterbium, vanadium, and oxygen. Traces of sodium, calcium, and scandium are also detected. Other elements, as lanthanum and cerium, are below the detection limits and have not been considered. On some spectra inhomogeneous presence of silicon is probably due to surface contamination.

The empirical formula calculated on the basis of $38 \mathrm{O}$ atoms apfu (consistent with members of the crichtonite supergroup) is $\left(\mathrm{Sr}_{0.70} \mathrm{Na}_{0.25} \mathrm{Ca}_{0.09}\right)_{(\Sigma=1.04)}\left(\mathrm{Y}_{0.62} \mathrm{U}_{0.18} \mathrm{Yb}_{0.09}\right.$ $\left.\mathrm{Sc}_{0.08}\right)_{(\Sigma=0.97)} \mathrm{Fe}_{2}^{+2}\left(\mathrm{Ti}_{12.66} \mathrm{Fe}_{4.78}^{3+} \mathrm{V}_{0.26}^{3+}\right)_{(\Sigma=17.70)} \mathrm{O}_{38}$, disregarding $\mathrm{Si}$ which can be considered contamination by

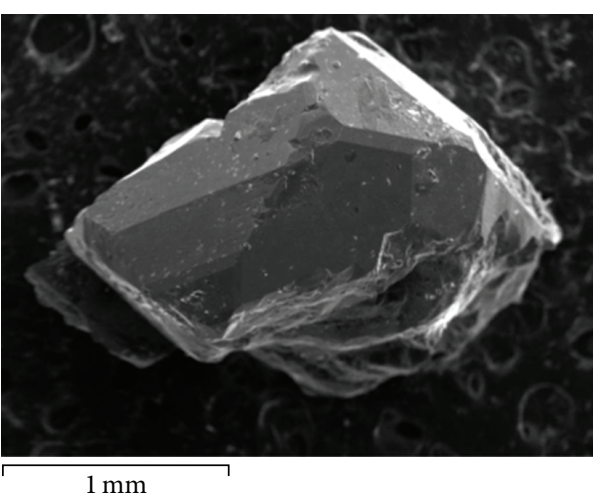

Figure 2: One of the two crystals investigated by Colomba, found in the old material of the Regional Museum and used for the EDS analysis.

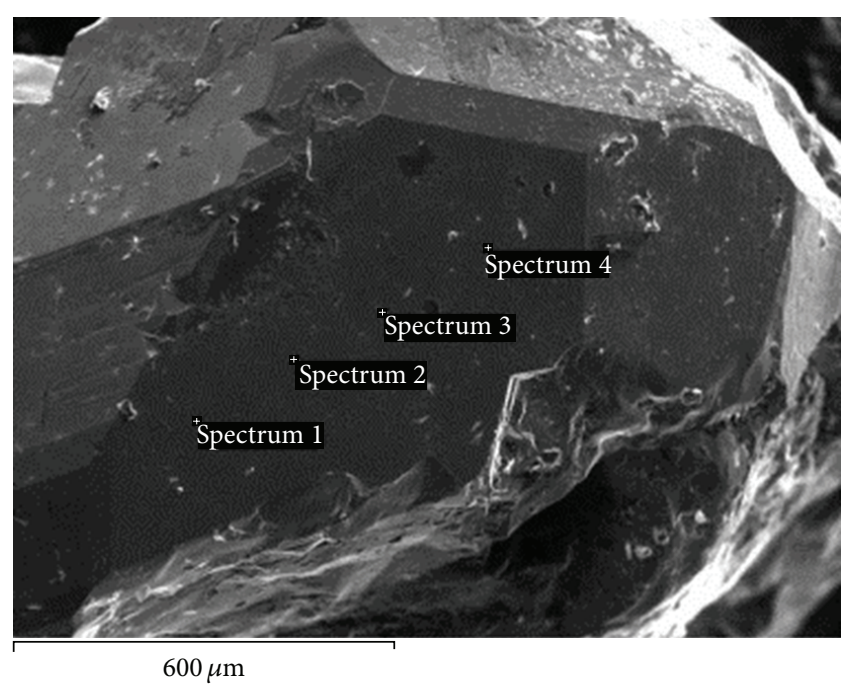

FIGURE 3: The position of some analyses points on one of the flat faces of the crystal.

quartz. The following simplified chemical formula is $\mathrm{Sr}(\mathrm{Y}, \mathrm{U}) \mathrm{Fe}_{2}(\mathrm{Ti}, \mathrm{Fe})_{18} \mathrm{O}_{38}$, in agreement with the composition of dessauite-(Y) (Orlandi et al. [8]).

4.1.2. $\mu$-Raman Spectroscopy. Due to the lack of the dessauite(Y) Raman spectra in the database we have compared the collected spectra to those of some mineral species that belong to the crichtonite supergroup, in particular gramaccioliite(Y) (Ciriotti and Bittarello personal communication) from the type locality of Sambuco (Stura Valley, Cuneo Province, Italy) and crichtonite, from the database (RRUFF ID 090006) (Laetsch and Downs [12]).

Figure 4 shows the comparison between the Raman spectra (recorded from 200 to $1000 \mathrm{~cm}^{-1}$ ) of the studied crystals and those of gramaccioliite-(Y) (Orlandi et al. [9]). It is possible to observe a close matching between the collected spectra.

The main Raman bands of dessauite-(Y) are located in the region between 600 and $800 \mathrm{~cm}^{-1}$; the strongest ones are at 
TABLE 2: Analytical data of the studied dessauite-(Y).

\begin{tabular}{lccc}
\hline & $\mathrm{Wt} \%$ & Range & Standard \\
\hline $\mathrm{SrO}$ & 4.06 & $3.46-4.50$ & $\mathrm{SrSO}_{4}$ \\
$\mathrm{Na} \mathrm{O}_{2}$ & 0.44 & $0.30-0.51$ & Albite \\
$\mathrm{CaO}$ & 0.29 & $0.19-038$ & Diopside \\
$\mathrm{Y}_{2} \mathrm{O}_{3}$ & 3.96 & $3.40-4.35$ & $\mathrm{Y}_{2} \mathrm{O}_{3}$ \\
$\mathrm{UO}_{3}$ & 2.86 & $2.65-3.10$ & $\mathrm{UO}_{2}$ \\
$\mathrm{Yb}_{2} \mathrm{O}_{3}$ & 1.01 & $0.79-1.20$ & $\mathrm{Yb}$ \\
$\mathrm{Sc}_{2} \mathrm{O}_{3}$ & 0.29 & $0.27-0.30$ & $\mathrm{Sc}$ \\
$\mathrm{Fe}_{2} \mathrm{O}_{3}^{*}$ & 21.50 & & $\mathrm{Fe}_{2} \mathrm{O}_{3}$ \\
$\mathrm{FeO}^{*}$ & 8.19 & & $\mathrm{Fe}_{2} \mathrm{O}_{3}$ \\
$\mathrm{TiO}_{2}$ & 57.01 & $56.26-58.28$ & $\mathrm{TiO}$ \\
$\mathrm{V}_{2} \mathrm{O}_{3}$ & 1.09 & $0.87-1.31$ & $\mathrm{~V}$ \\
\hline $\mathrm{Total}^{2}$ & 100.69 & $97.33-104.20$ & \\
\hline
\end{tabular}

${ }^{*} \mathrm{Fe}_{\mathrm{TOT}}$ has been recalculated as combination of $\mathrm{Fe}^{3+}$ and $\mathrm{Fe}^{2+}$. $\mathrm{Fe}_{\mathrm{TOT}}=29.69 \mathrm{Wt} \%$ (range 29.08-30.27).

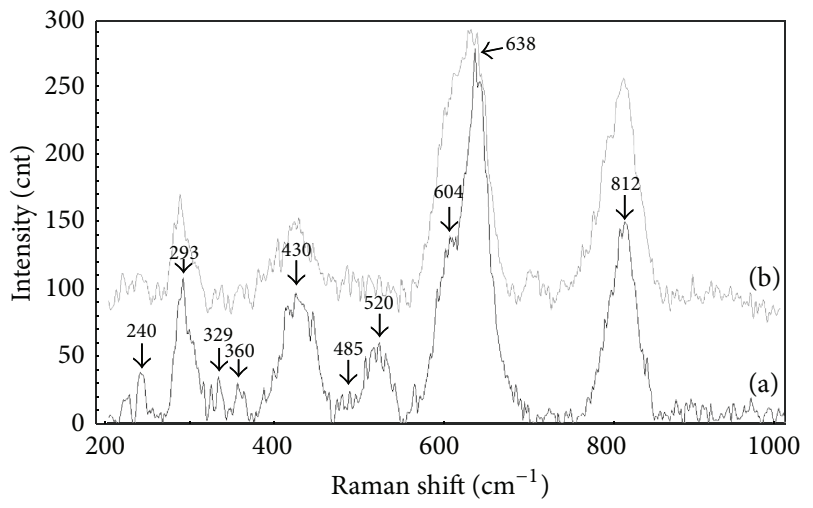

FIGURE 4: (a) Raman spectrum of studied dessauite-(Y) ("mohsite" of Colomba) and (b) of gramaccioliite-(Y) sample (Ciriotti and Bittarello personal communication) in the $200-1000 \mathrm{~cm}^{-1}$ region.

604,683 , and $812 \mathrm{~cm}^{-1}$. Other weaker, broad, and multiple bands are visible at 240, 293, 329, 360, 430, 485, and $520 \mathrm{~cm}^{-1}$. Due to the strong fluorescence, even in the region of the bending and stretching of $\mathrm{O}-\mathrm{H}$ bonds, no detectable Raman signals could be collected.

4.1.3. X-Ray Crystallography. X-ray powder and singlecrystal diffraction data were obtained from a small fragment $(0.05 \times 0.05 \times 0.02 \mathrm{~mm})$ of one of the analyzed specimens.

Structurally, the sample studied crystallizes in the trigonal system, space group $R-3$, with the unit-cell parameters: $a=$ 10.376(3) $\AA, c=20.903(6) \AA$, and $V=1949(1) \AA^{3}$ and the powder diffraction data are shown in Table 3 . All the data are in accordance with the crystallographic feature of the dessauite-(Y) (Orlandi et al. [8]).

\section{Conclusions}

EDS analysis showed the presence of major elements like iron, titanium, and oxygen. Microprobe analyses also revealed amounts of strontium, yttrium, ytterbium, vanadium, and
TABLE 3: X-ray powder diffraction data of the studied dessauite-(Y).

\begin{tabular}{lc}
\hline$d_{\text {obs }}(\AA)$ & $I_{\text {rel }}$ \\
\hline 4.0179 & 11.2 \\
3.6496 & 27.6 \\
3.4005 & 21 \\
3.0472 & 32.9 \\
2.9138 & 17 \\
2.7685 & 13.6 \\
2.5432 & 15.9 \\
2.3412 & 27.3 \\
1.9734 & 13.8 \\
1.7632 & 9.8 \\
1.662 & 81 \\
1.6593 & 100 \\
1.6485 & 83.8 \\
1.5818 & 9.9 \\
1.4915 & 10.6 \\
1.4491 & 8 \\
1.4054 & 7.1 \\
1.3552 & 9.7 \\
\hline
\end{tabular}

Only reflections with $I_{\text {rel }}>7 \sigma\left(I_{\text {rel }}\right)$ are listed.

uranium, all of them below 5\% in weight. Silicon (average $0.20 \%$ in weight) was not considered because it might derive from surface contamination. The specimens, in fact, were not polished or treated in any way but only graphite coated and could possibly retain other minerals or alteration layers on their surface, even though optical microscopy and SEM observation helped in choosing clean portion where analyses were performed.

Chemical data, crystallographic features, and Raman spectrum permit identifying the mineral as a $\mathrm{Pb}$-free dessauite-(Y), member of the crichtonite supergroup, characterized by the presence of $\mathrm{Sr}, \mathrm{Y}, \mathrm{Fe}^{3+}$, and $\mathrm{Ti}$ as dominants at the relevant structural sites. In the following Table 4 we show 
TABLE 4: Comparison of chemical data (apfu) between "mohsite of Lévy" as reported in Kelly et al. [6] and "mohsite of Colomba" (this paper).

\begin{tabular}{|c|c|c|}
\hline Element & $\begin{array}{l}\text { Specimen from Lacroix collection (Kelly et al. [6]) } \\
\qquad a p f u\end{array}$ & $\begin{array}{l}\text { Specimen from the mineralogical collection of Turin } \\
\text { University (this study) } \\
\qquad a p f u\end{array}$ \\
\hline $\mathrm{Sr}$ & 0.48 & 0.70 \\
\hline $\mathrm{Pb}$ & 0.44 & \\
\hline $\mathrm{Na}$ & & 0.25 \\
\hline $\mathrm{Ca}$ & 0.07 & 0.09 \\
\hline$\square$ & 0.01 & \\
\hline${ }^{\mathrm{XII}} \mathrm{A}$ & 1.00 & 1.04 \\
\hline $\mathrm{Y}$ & 0.42 & 0.62 \\
\hline $\mathrm{Zn}$ & 0.20 & \\
\hline $\mathrm{U}$ & & 0.18 \\
\hline $\mathrm{Mn}^{2+}$ & 0.11 & \\
\hline $\mathrm{La}$ & 0.08 & \\
\hline $\mathrm{Ce}$ & 0.06 & \\
\hline $\mathrm{Nd}$ & 0.01 & \\
\hline $\mathrm{Yb}$ & & 0.09 \\
\hline Sc & & 0.08 \\
\hline$\square$ & 0.12 & \\
\hline${ }^{\mathrm{VI}} \mathrm{B}$ & 1.00 & 0.97 \\
\hline $\mathrm{Fe}^{2+}$ & 1.57 & 2.00 \\
\hline $\mathrm{Mn}^{2+}$ & 0.44 & \\
\hline${ }^{\mathrm{IV}} \mathrm{T}_{2}$ & 2.01 & 2.00 \\
\hline $\mathrm{Ti}$ & 13.43 & 12.66 \\
\hline $\mathrm{Fe}^{3+}$ & 4.46 & 4.78 \\
\hline $\mathrm{V}^{5+}$ & 0.05 & 0.26 \\
\hline $\mathrm{Al}$ & 0.04 & \\
\hline $\mathrm{Cr}$ & 0.02 & \\
\hline${ }^{\mathrm{VI}} \mathrm{C}_{18}$ & 18.00 & 18.00 \\
\hline $\mathrm{O}_{38}$ & 38.00 & 38.00 \\
\hline
\end{tabular}

The symbol $\square$ state for vacancy.

the comparison between the old data of Kelly et al. [6] and our new data.

In conclusion, the "mohsite" of Lévy (samples of the Lacroix collection from Le Plate Muratouse, Dauphiné, the current French Department of Hautes-Alpes), studied by Kelly et al. [6], and the samples found by Colomba at La Beaume, Oulx, Italy, studied in 1902 and stored by the same author in the collection of the Turin University at the MRSN with the label "Manaccanite (Mohsite)," are both dessauite(Y).

To outline the scarcity of this mineral, the Le Plate Muratouse represents the first occurrence of dessauite-(Y) from France and the occurrence of La Beaume represents the first probed finding for the Piedmont region, the fourth for Italy, and the fifth in the world. Anyway, we are almost sure that the sample object of the present paper is one of the oldest specimens of dessauite-(Y) found.

Finally, with this paper, a complete clarification is given about the identity of the "minerals" historically known as "mohsite of Lévy" and "mohsite of Colomba" and a bit everywhere erroneously reported (e.g., Egleston [13], de Fourestier [14], Bayliss [15], and Internet pages) as "manaccanite” (axotomous iron), Pb-rich crichtonite, or ilmenite.

\section{Conflict of Interests}

The authors declare that there is no conflict of interests regarding the publication of this paper.

\section{References}

[1] A. Lévy, "On a new mineral species," Philosophical Magazine, vol. 1, Series 2, pp. 221-223, 1827.

[2] A. Lacroix, Minéralogie de la France et de ses colonies. Tome III Premier fascicule, Librarie Polytechnique, Paris, France, 1901.

[3] L. Colomba, "Sulla mohsite della Beaume (Alta valle della Dara Riparia)," Atti della Reale Accademia delle scienze di Torino, vol. 37, pp. 491-500, 1902 (Italian). 
[4] F. Zambonini, "L. Colomba, (in Turin). Über der Mohsit aus der Beaume im oberen Dora Ripariatale," Zeitschrift für Kristallographie und Mineralogie, vol. 40, pp. 99-100, 1905 (German).

[5] E. Costa and L. M. Gallo, "The history of the discredited mohsite," Plinius, vol. 37, p. 303, 2011.

[6] P. R. Kelly, I. H. Campbell, I. E. Grey, and B. M. Gatehouse, "Additional data on loveringite $(\mathrm{Ca}, \mathrm{REE})(\mathrm{Ti}, \mathrm{Fe}, \mathrm{Cr})_{21} \mathrm{O}_{38}$ and mohsite discredited," Canadian Mineralogist, vol. 17, pp. 635638, 1979.

[7] B. M. Gatehouse, I. E. Grey, I. H. Campbell, and P. R. Kelly, "The crystal structure of loveringite-a new member of the crichtonite group," American Mineralogist, vol. 63, pp. 28-36, 1978.

[8] P. Orlandi, M. Pasero, G. Duchi, and F. Olmi, "Dessauite, $(\mathrm{Sr}, \mathrm{Pb})(\mathrm{Y}, \mathrm{U})\left(\mathrm{Ti}, \mathrm{Fe}^{3+}\right)_{20} \mathrm{O}_{38}$, a new mineral of the crichtonite group from Buca della Vena Mine, Tuscany, Italy," American Mineralogist, vol. 82, no. 7-8, pp. 807-811, 1997.

[9] P. Orlandi, M. Pasero, N. Rotiroti, F. Olmi, F. Demartin, and Y. Moëlo, "Gramaccioliite-(Y), a new mineral of the crichtonite group from Stura Valley, Piedmont, Italy," European Journal of Mineralogy, vol. 16, no. 1, pp. 171-175, 2004.

[10] P.-A. Wülser, J. Brugger, and N. Meisser, "The crichtonite group of minerals: a review of the classification," Bulletin de liaison de la Société Francaise de Minéralogie et Cristallographie, vol. 16, pp. 76-77, 2004.

[11] M. Wojdyr, "Fityk: a general-purpose peak fitting program," Journal of Applied Crystallography, vol. 43, no. 5, pp. 1126-1128, 2010.

[12] T. Laetsch and R. T. Downs, "Software for identification and refinement of cell parameters from powder diffraction data of minerals using the RRUFF project and American Mineralogist Crystal Structure Databases," in Proceedings of the 19th General Meeting of the International Mineralogical Association, Kobe, Japan, July 2006.

[13] T. Egleston, Catalogue of Minerals and Synonyms, John Wiley \& Sons, New York, NY, USA, 3rd edition, 1892.

[14] J. de Fourestier, Glossary of Mineral Synonyms, vol. 2 of The Canadian Mineralogist Special Publication, Mineralogical Association of Canada, Québec, Canada, 1999.

[15] P. Bayliss, Glossary of Obsolete Mineral Names, The Mineralogical Record, Tucson, Ariz, USA, 2000.

[16] S. J. Mills, L. Bindi, M. Cadoni, A. R. Kampf, M. E. Ciriotti, and G. Ferraris, "Paseroite, $\mathrm{PbMn}^{2+}\left(\mathrm{Mn}^{2+}, \mathrm{Fe}^{2+}\right)_{2}\left(\mathrm{~V}^{5+}, \mathrm{Ti}, \mathrm{Fe}^{3+}\right.$, 口) ${ }_{18} \mathrm{O}_{38}$, a new member of the crichtonite group," European Journal of Mineralogy, vol. 24, pp. 1061-1067, 2012.

[17] L. A. D. Menezes Filho, N. V. Chukanov, R. K. Rastsvetaeva et al., "Almeidaite, IMA, 2013-020. CNMNC Newsletter No. 16, 2013, 2705," Mineralogical Magazine, vol. 77, pp. 2695-2709, 2013.

[18] P.-A. Wülser, N. Meisser, J. Brugger et al., "Cleusonite, $(\mathrm{Pb}, \mathrm{SR})\left(\mathrm{U}^{4+}, \mathrm{U}^{6+}, \mathrm{Zn}\right)_{2}\left(\mathrm{Ti}, \mathrm{Fe}^{2+}, \mathrm{Fe}^{3+}\right)_{18}(\mathrm{O}, \mathrm{OH})^{38}$, a new mineral species of the crichtonite group from the western Swiss Alps," European Journal of Mineralogy, vol. 17, no. 6, pp. 933-942, 2005.

[19] I. E. Grey and D. J. Lloyd, "Crystal structure of senaite," Acta Crystallographica, vol. B32, pp. 1509-1513, 1976.

[20] B. M. Gatehouse, I. E. Grey, and P. R. Kelly, "The crystal structure of davidite," American Mineralogist, vol. 64, pp. 10101017, 1979.

[21] I. E. Grey and B. M. Gatehouse, "The crystal structure of landauite, $\mathrm{NaMnZn}_{2}(\mathrm{Ti}, \mathrm{Fe})_{6} \mathrm{Ti}_{12} \mathrm{O}_{38}$," Canadian Mineralogist, vol. 16, pp. 63-68, 1978.
[22] J. Zhang, J. Ma, and L. Li, “The crystal structure and crystal chemistry of the lindsleyite and mathiasite," Geological Review, vol. 34, pp. 132-144, 1988 (Chinese).

[23] C. Biagioni, P. Orlandi, M. Pasero, F. Nestola, and L. Bindi, "Mapiquiroite, $(\mathrm{Sr}, \mathrm{Pb})(\mathrm{U}, \mathrm{Y}) \mathrm{Fe}_{2}\left(\mathrm{Ti}, \mathrm{Fe}^{3+}\right)_{18} \mathrm{O}_{38}$, a new member of the crichtonite group from the Apuan Alps, Tuscany, Italy," European Journal of Mineralogy, vol. 26, no. 3, 2014.

[24] B. M. Gatehouse, I. E. Grey, and J. R. Smyth, "Structure refinement of mathiasite, $\left(\mathrm{K}_{0.62} \mathrm{Na}_{0.14} \mathrm{Ba}_{0.14} \mathrm{Sr}_{0.10}\right) \Sigma_{1.0}\left(\mathrm{Ti}_{12.90}\right.$ $\left.\mathrm{Cr}_{3.10} \mathrm{Mg}_{1.53} \mathrm{Fe}_{2.15} \mathrm{Zr}_{0.67} \mathrm{Ca}_{0.29}(\mathrm{~V}, \mathrm{Nb}, \mathrm{Al})_{0.36}\right) \Sigma_{21.0} \mathrm{O}_{38}$, "Acta Crystallographica, vol. C39, no. 4, pp. 421-422, 1983. 

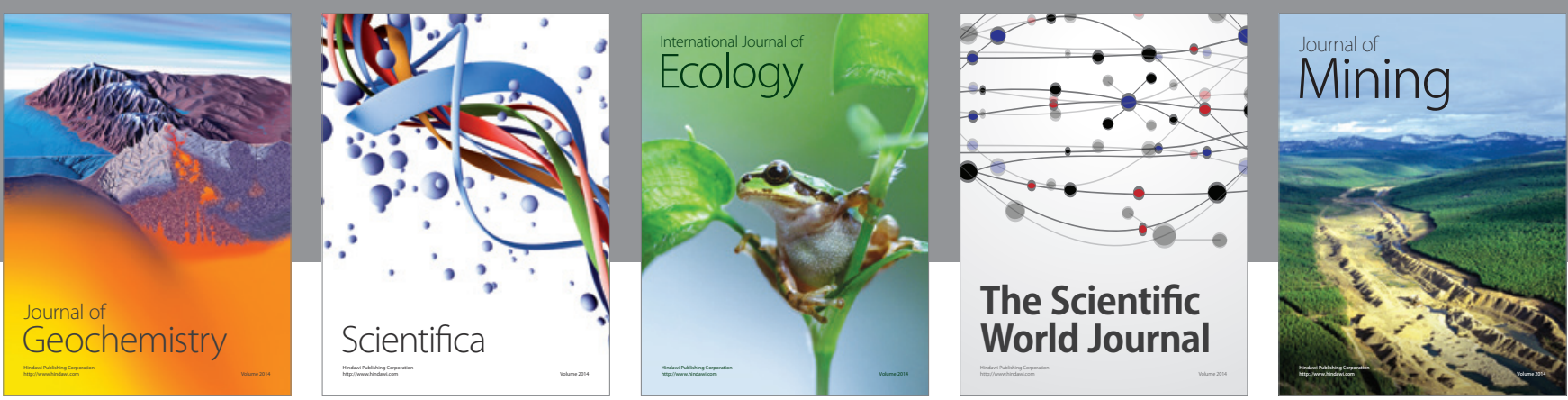

The Scientific World Journal
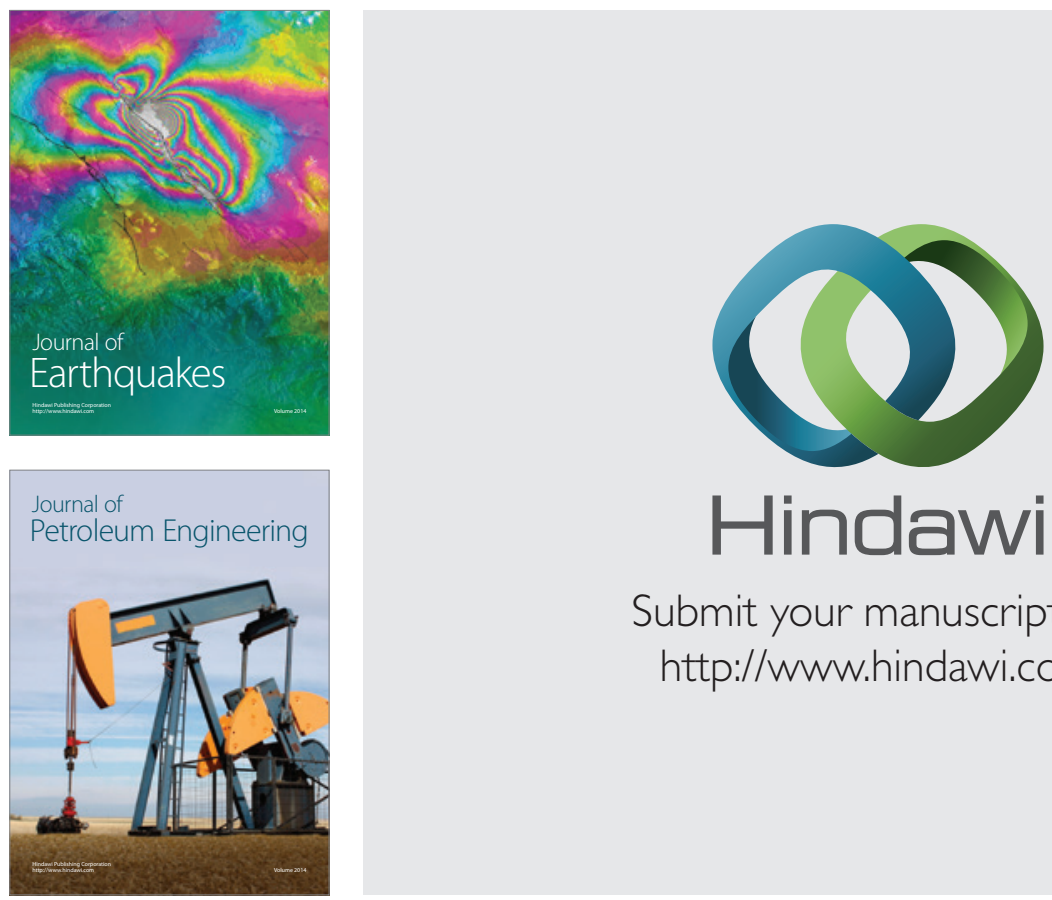

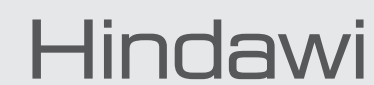

Submit your manuscripts at

http://www.hindawi.com
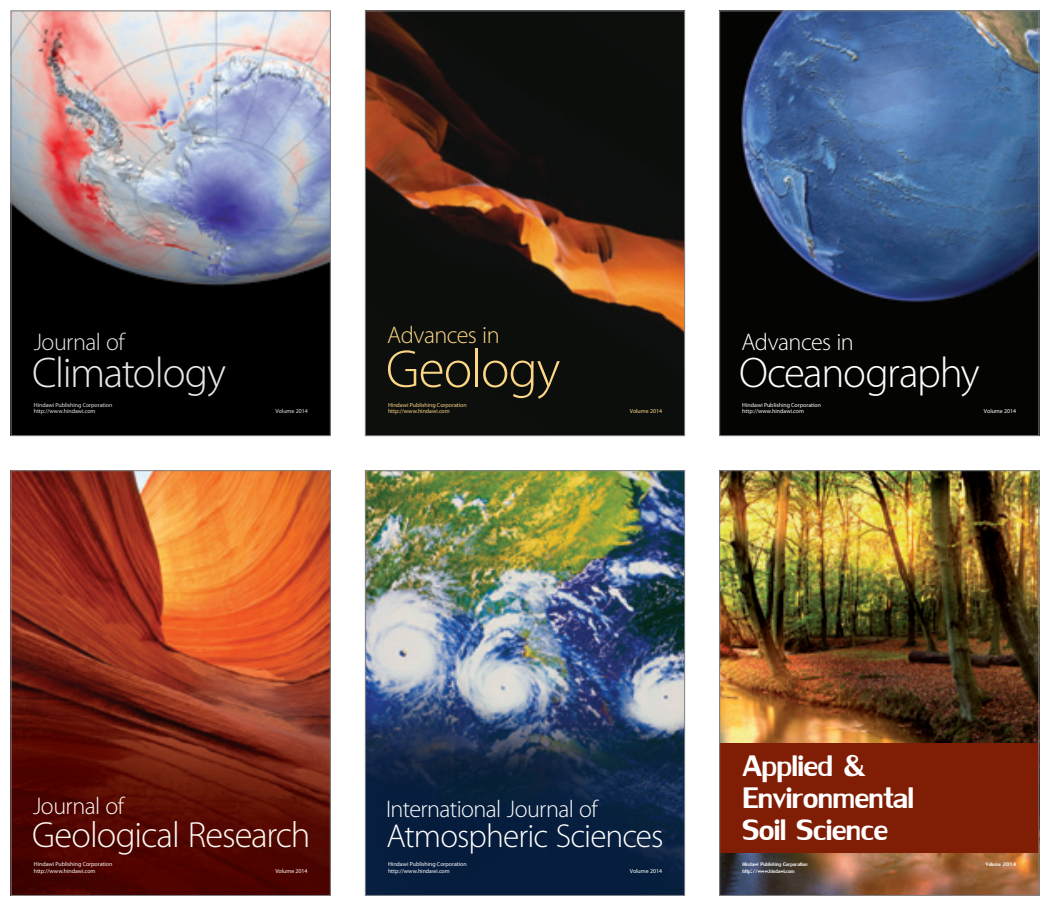
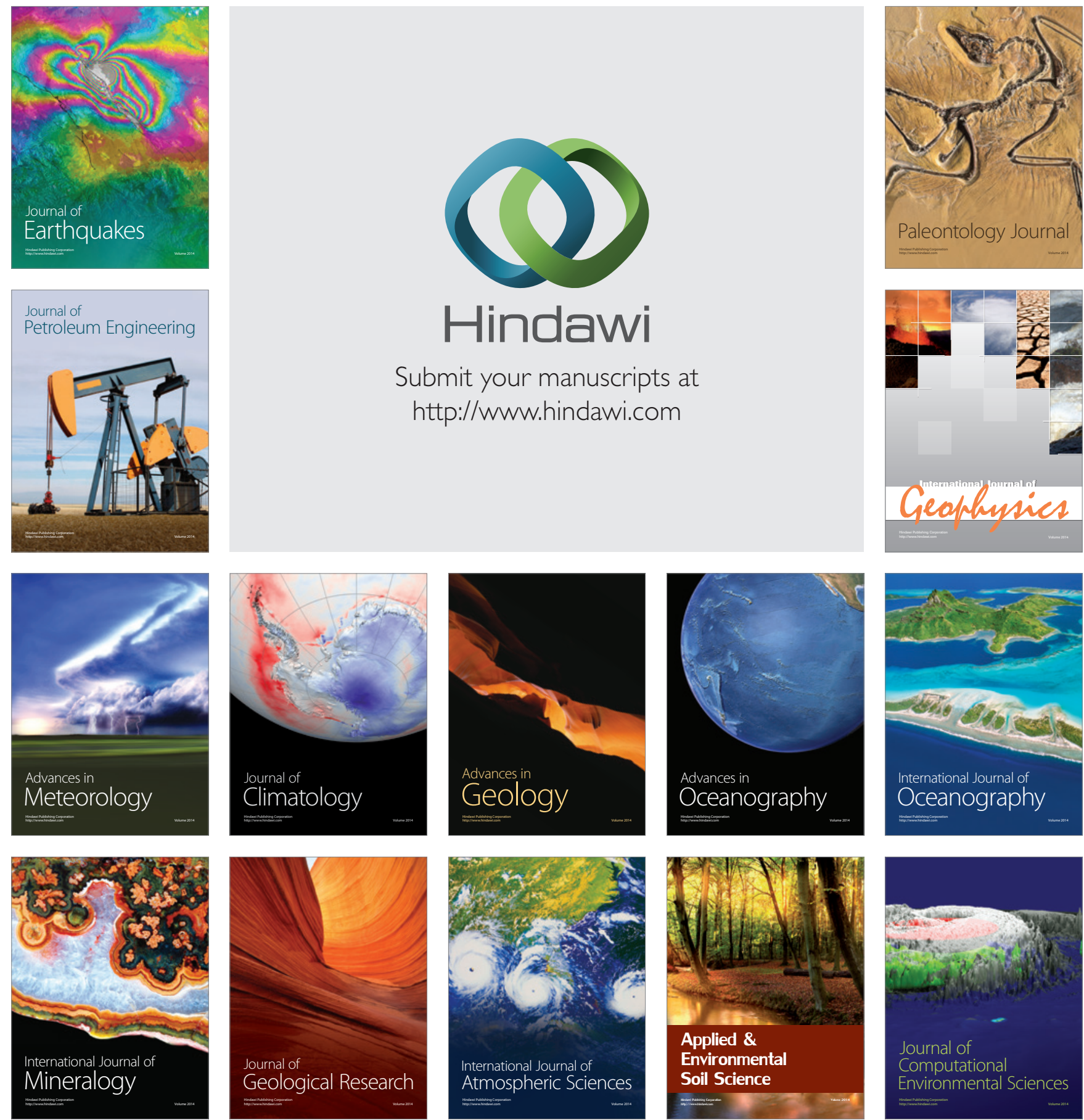